\title{
ARSENIC INDUCED VASCULAR ENDOTHELIAL DYSFUNCTION PREVENTED BY ANTIOXIDANTS IN FETAL KIDNEYS OF ALBINO MICE
}

\author{
FARIHA QURESHI ${ }^{1}$, MOHAMMAD TAHIR ${ }^{2}$. \\ ${ }^{1}$ Department of Anatomy, Akhtar Saeed Medical\& Dental College, Lahore, \\ ${ }^{2}$ Department of Anatomy, University of Health Sciences, Lahore.
}

\begin{abstract}
:
Background: Cardiovascular diseases and hypertension has a significant correlation with chronic arsenic exposure through drinking water.

Objectives: To investigate the prevention of sodium arsenate induced vascular disorders by Vitamins $\mathrm{C} \& \mathrm{E}$ in fetal renal blood vessels of albino mice.

Methods: Gravid albino mice of BALB/c strain (twenty-four) were randomly divided into 4 groups having 6 animals each. Control group A was inoculated with $0.1 \mathrm{ml} / \mathrm{kg} /$ day distilled water $\mathrm{I} / \mathrm{P}$ for 18 days. Animals of groups B, C \& D were given a single $\mathrm{I} / \mathrm{P}$ injection of sodium arsenate $35 \mathrm{mg} / \mathrm{kg}$ on $8^{\text {th }} \mathrm{GD}$, whereas groups $\mathrm{C}$ and D were also injected with Vitamin C, $9 \mathrm{mg} / \mathrm{kg} /$ day and vitamin E $15 \mathrm{mg} / \mathrm{kg} /$ day by I/P route, beginning from $8^{\text {th }} \mathrm{GD}$ and continued for the entire pregnancy period. On $18^{\text {th }}$ day of gestation fetal kidneys were extracted. Histological examination of renal blood vessels was performed for any discernable congestion, endothelial disruption and hyalinization and frequency of changes were expressed as percentages.

Results: In group (B) sodium arsenate induction resulted in congestion of blood vessels, hemorrhages in glomerular capillaries and thickening of endothelial walls. The addition of Vitamins $C$ and $E$ in groups $C \& D$ respectively had reduced the congestion and endothelial thickening. Mean score of histological changes was statistically significant.

Conclusions: The results showed the antioxidant prospective of Vitamins $\mathrm{C}$ and $\mathrm{E}$ in combating against the vascular lesions induced by sodium arsenate.
\end{abstract}

Key Words: Vascular injury, vascular permeability, sodium arsenate, oxidative stress.

How to cite this article: Qureshi F, Tahir M. Arsenic induced vascular endothelial dysfunction prevented by antioxidants in fetal kidneys of albino mice. Pak Postgrad Med J 2020;31(1): 18-23

This is an Open Access article distributed under the terms of the Creative Commons Attribution License (http://creativecommons.org/licenses/by/3.0), which permits unrestricted use, distribution, and reproduction in any medium, provided the original work is properly cited.

DOI: HTTPS//DOI.ORG/10.51642/ppmj. v31i01.358

Correspondence to: Fariha Qureshi, Associate Professor, Department of Anatomy, Akhtar Saeed Medical\& Dental College \&University of Health Sciences, Lahore, Pakistan.

Email: fariha.qureshi@live.com

\section{INTRODUCTION:}

Arsenic exposure through contaminated drinking water predisposes humans to various cardiovascular diseases, such as hypertension, atherosclerosis, inflammation and vascular permeability. ${ }^{1}$ In addition the chronic arsenic contact results in nephrotoxicity, hepatotoxicity and neurotoxicity. ${ }^{2}$ According to the WHO guideline the permissible level of arsenic in drinking water is $10 \mathrm{ppb}$ but presently this level has exceeded in most of the arsenic-affected Asian countries $^{3}$. Epidemiological studies have revealed that concentration of arsenic in drinking water if exceeded to $200-300 \mu \mathrm{g} / \mathrm{L}$ was related with higher mortality rates from diabetes mellitus, cerebrovascular disease and kidney diseases in both gender. ${ }^{4}$ Arsenic toxicity effects the vascular endothelium profoundly as demonstrated in rats by Sharma, 2013. ${ }^{5}$

Waghe et.al 2015, experimented on rats with different concentrations of sodium arsenite in drinking water, blood pressure was recorded weekly. The investigators found that there was a dose dependent increase in systolic, diastolic and mean arterial blood pressure from $7^{\text {th }}$ week onwards. ${ }^{6}$ In another study the scientists administered zinc with arsenic to reverse the 
renal toxicity, zinc enhanced the antioxidant system and reversed the renal damage. ${ }^{7}$

Kesavan et.al 2014, exposed rats for 90 days with arsenic in drinking water and then administered atorvastatin a drug used for reducing the risk of cardiovascular diseases for 30 days. They collected blood on $91^{\text {st }}$ day for serum C-reactive protein analysis which showed that atorvastatin has the potential to improve arsenic-induced vascular leakage. ${ }^{8}$ In another study the oxidative stress induced by arsenic on vascular endothelium was reduced by fenofibrate a drug used to treat abnormal blood lipid levels. ${ }^{9}$

Arsenic induces oxidative stress by various cellular mechanisms and different strategies have been investigated by researchers to overcome the arsenicmediated damages both in vitro and vivo models. ${ }^{10}$

This study evaluated the potential of vitamins $\mathrm{C}$ and $\mathrm{E}$ as antioxidants to reduce the oxidative stress induced by sodium arsenate effecting the vascular endothelium of fetal renal vessels of albino mice.

\section{METHODS}

Experimental controlled trial was conducted on thirty-two gravid mice of BALB/c strain (twenty-four females and eight males) under controlled environment (temperature $22 \pm 1{ }^{\circ} \mathrm{C}$ and humidity $40 \%-60 \%$ ) with a 12 hour light and dark cycle. The animals were fed on standard rodent diet and distilled water ad libitum. The pregnant females were randomly divided into four groups with six animals in each group. The drugs were administered intraperitoneally as shown in table 1 .

Table 1: Table showing number of animals, drug, dose, duration of administration in various groups.

\begin{tabular}{|c|c|c|c|c|}
\hline Groups & Animals & $\begin{array}{l}\text { Drug/distilled } \\
\text { water }\end{array}$ & $\begin{array}{l}\text { Dosage/ } \\
\text { day }\end{array}$ & Duration \\
\hline$\overline{\mathrm{A}}$ & 6 & distilled water & $0.1 \mathrm{ml} / \mathrm{kg}$ & 1-18 days \\
\hline B & 6 & Sodium Arsenate & $35 \mathrm{mg} / \mathrm{kg}$ & $\begin{array}{l}8^{\text {th }} \text { day of } \\
\text { gestation }\end{array}$ \\
\hline & & Sodium Arsenat & $35 \mathrm{mg} / \mathrm{kg}$ & $8^{\text {th }} \mathrm{GD}$ \\
\hline $\mathrm{C}$ & 6 & $\begin{array}{l}+ \\
\text { Vitamin C }\end{array}$ & $9 \mathrm{mg} / \mathrm{kg}$ & 1-18 days \\
\hline & & Sodium Arsenat & $35 \mathrm{mg} / \mathrm{kg}$ & $8^{\text {th }} \mathrm{GD}$ \\
\hline $\mathrm{D}$ & 6 & $\begin{array}{l}+ \\
\text { Vitamin E }\end{array}$ & $15 \mathrm{mg} / \mathrm{kg}$ & 1-18 days \\
\hline
\end{tabular}

The animals were sacrificed on $18^{\text {th }}$ day of gestation. The uterine horns were exposed which appeared beaded by the fetuses. Fetal kidneys were extracted from the fetuses and fixed in neutral buffered formalin $10 \%$, washed, dehydrated, cleared and embedded in paraffin. The paraffin embedded blocks were sectioned at 3-5micron thickness and stained with Hematoxylin and Eosin. Stained sections were studied under a light microscope (Leica DM 1000) at magnification of X100, X200, X400. Three coronal sections from each kidney were randomly chosen and examined qualitatively for the histological components of the kidney, the renal corpuscles and blood vessels. The blood vessels were assessed for any distinct change as

1) Congestion of interlobular arteries \& glomerular tufts.

2) Hyalinization

3) Endothelial thickening or disruption and these histological variables were scored as.

$0=$ No change, $1-3=$ Mild change, $4-6=$ Moderate change, 7-9 = Severe change.

Mean scores of histological changes were calculated. The frequency of histological changes in renal blood vessels was expressed in percentage.

The results were expressed as mean \pm SD (Standard Deviation). Statistical analyses were performed using the SPSS version 18.0. The parametric test one-way ANOVA was used for data analysis and comparison was done using Tukey post-hoc test. $\mathrm{P}$ value of 0.05 was considered significant.

\section{RESULTS}

The blood vessels of control group (A) showed blood cells in lumen, lined by the thin endothelium, glomerular capillaries with intact endothelium surrounded by interlobular arteries and normal number of cells in lumen (Fig 1, a \&b). Sodium arsenate exposure in group (B) resulted in congestion of blood vessels, endothelial lining was intact but showed thickening of wall, hyalinization was not observed. Hemorrhages were detected in glomerular capillary tufts, the parietal layers of capsule were intact, adhesions between capillary tuft and capsule were common (Fig 2, a \& b). In groups $\mathrm{C} \& \mathrm{D}$ the supplementation of Vitamins $\mathrm{C}$ and $\mathrm{E}$ respectively had reduced the congestion of blood vessels and endothelial thickening. The renal corpuscles appeared to be rounded, intact glomeruli surrounded by Bowman's spaces all around and adhesions were not present (Figs $3 \& 4$ ). The mean scoring of histological changes was tested by ANOVA which was statistically significant (Table 2). Multiple comparisons between the groups were verified by post hoc test Tukey (Table 3). The frequency of changes in blood vessels was expressed in percentages (Table 4). 

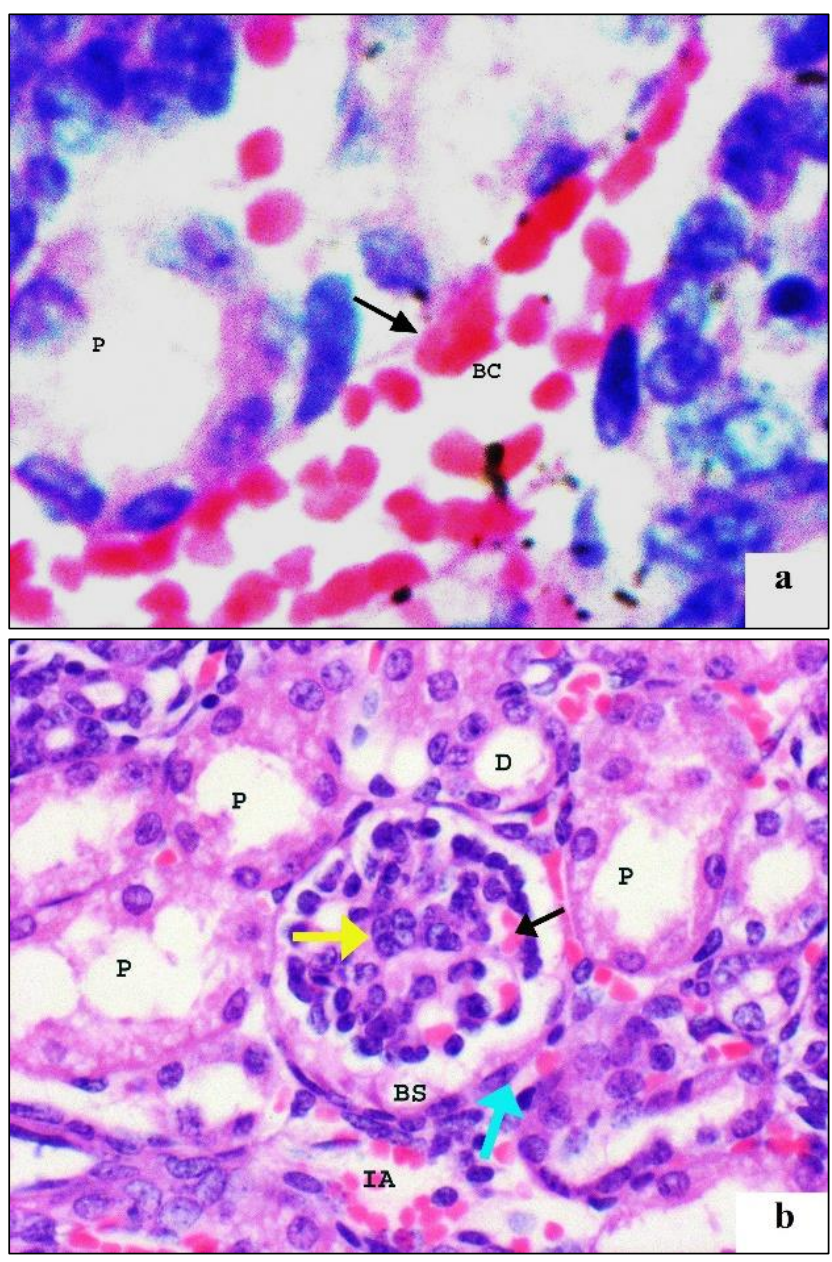

Fig.1: Photomicrographs of mice fetal kidney (Control group- A). (a) Interlobular artery (arrow) with blood cells (BC) in lumen, thin endothelial lining. H\&E, X400. (b) Renal corpuscle, showing the glomerulus with mesangial cell nuclei grouped in center (yellow arrow) capillary lumen displaying RBC (black arrow), clear Bowman's space (BS), flattened nuclei (blue arrow) of capsule squamous epithelium, surrounded by interlobular arteries with blood cells in lumen (IA), proximal (P) and distal (D) convoluted tubules. H\&E, X200.
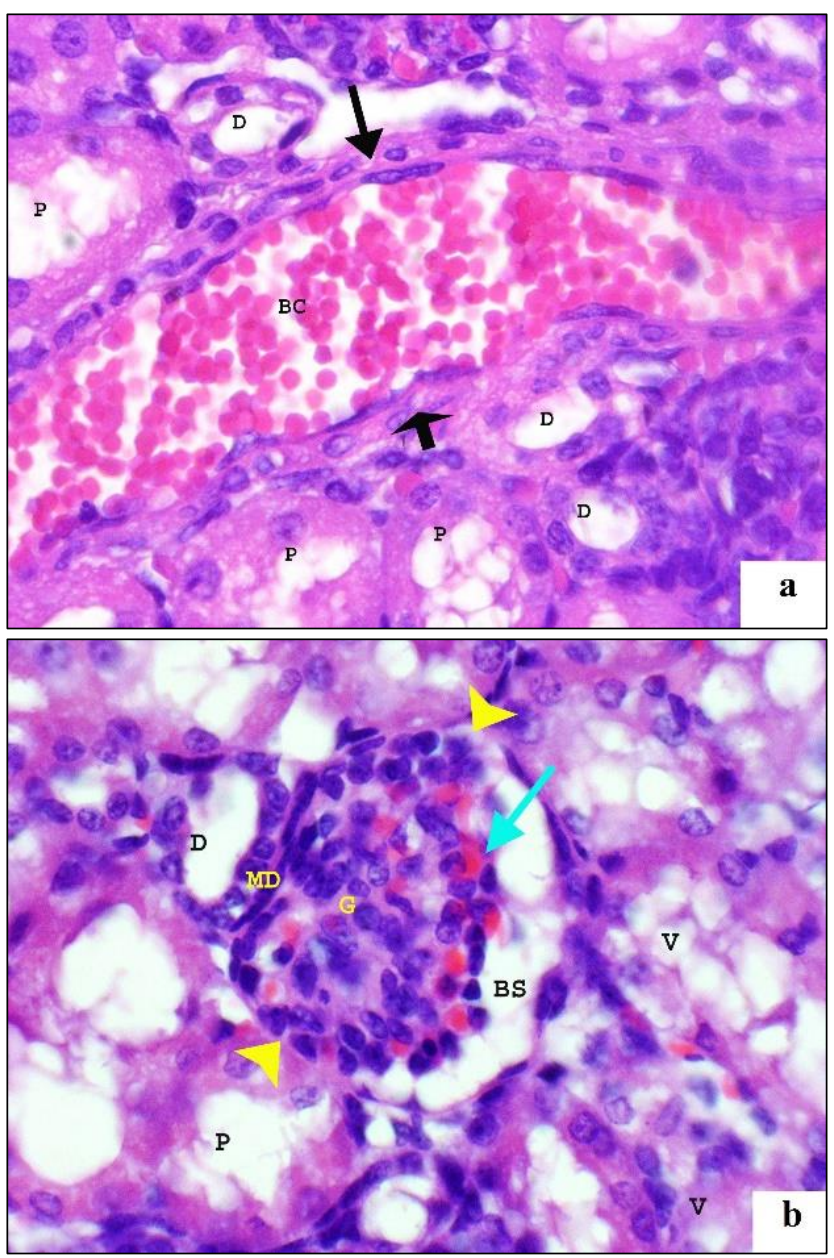

Figure 2: Photomicrographs of mice fetal kidney (Group. B): (a) showing interlobular artery congested with blood cells (BC) and thickening of endothelial walls (arrows); surrounded by proximal (P) and distal (D) tubules exhibiting cytoplasmic vacuolation. H\&E, X400. (b) The glomerular tuft $(\mathrm{G})$, hemorrhages are apparent in capillaries (blue arrow) adhesions were observed between (G) and capsule (yellow arrow heads, surrounded by PCT (P) showing vacuolation (V) and distal convoluted tubule (D). H\&E, X200.

Table 2: Comparison of mean scoring of histological changes in blood vessels of mice fetal kidneys per 10 fields among various groups.

\begin{tabular}{|c|c|c|c|c|c|c|c|c|c|}
\hline \multirow[t]{2}{*}{ Parameter } & \multicolumn{2}{|c|}{$\begin{array}{c}\text { A } \\
\text { Control }(n=40)\end{array}$} & \multicolumn{2}{|c|}{$\begin{array}{c}\text { B } \\
\text { Sodium } \\
\text { arsenate }(n=40)\end{array}$} & \multicolumn{2}{|c|}{$\begin{array}{c}\mathrm{C} \\
\text { Sodium } \\
\text { arsenate }+ \text { Vit C } \\
(\mathrm{n}=40)\end{array}$} & \multicolumn{2}{|c|}{$\begin{array}{c}\text { D } \\
\text { Sodium arsenate + } \\
\text { Vit E }(n=40)\end{array}$} & \multirow[t]{2}{*}{$\mathrm{p}$-value } \\
\hline & Mean & S.D & Mean & SD & Mean & SD & Mean & SD & \\
\hline $\begin{array}{l}\text { Scoring of Parameters of } \\
\text { blood vessels. }\end{array}$ & 0.9 & 0.2 & 6.9 & 0.5 & 2.0 & 0.3 & 4.7 & 0.6 & $0.000 *$ \\
\hline
\end{tabular}

* The mean difference is statistically highly significant 


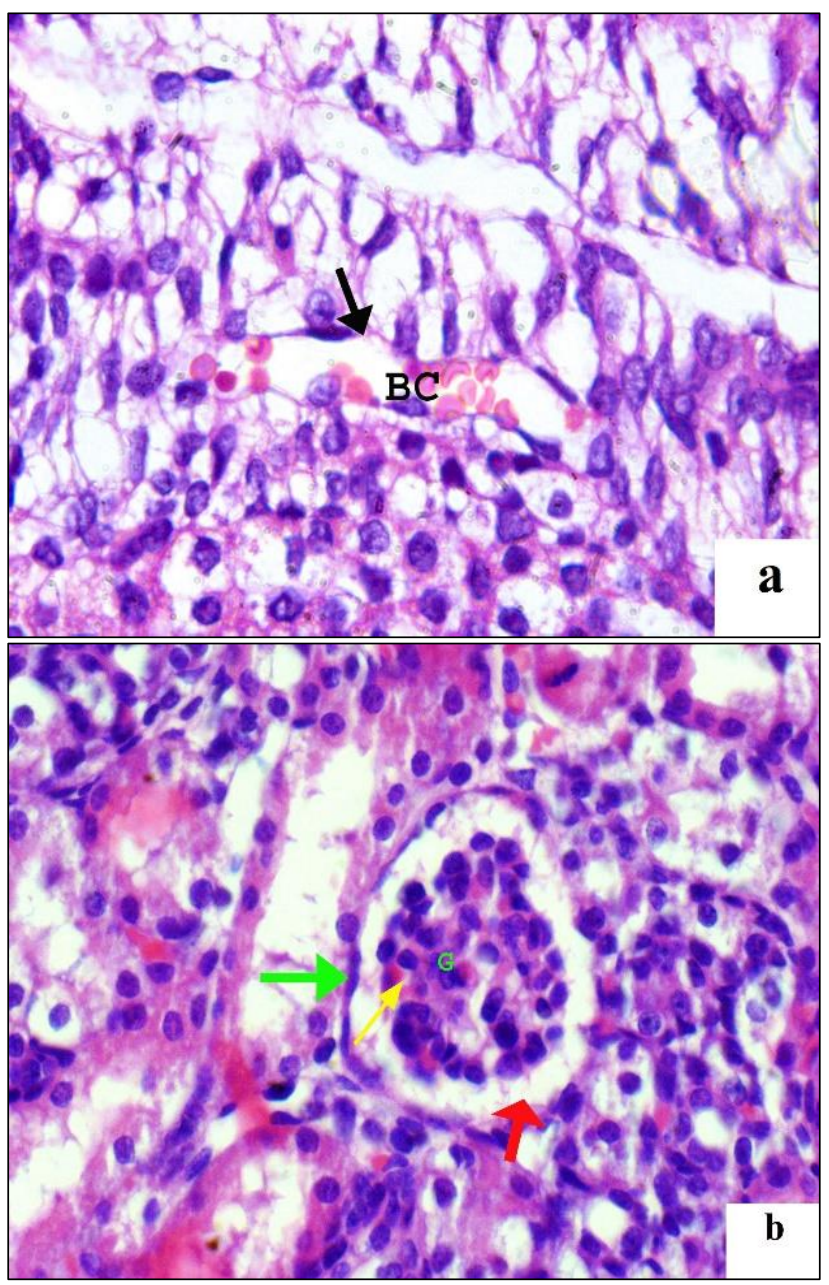

Figure 3: Photomicrographs of mice fetal kidney (Group. C): (a) Interlobular artery showing blood cells in lumen (BC), lined with thin endothelium (arrow) H\&E, X400. (b)Renal corpuscle showing glomerulus $(\mathrm{G})$, capillaries with RBC (yellow arrow), clear Bowman's space (red arrow) H\&E, X200.
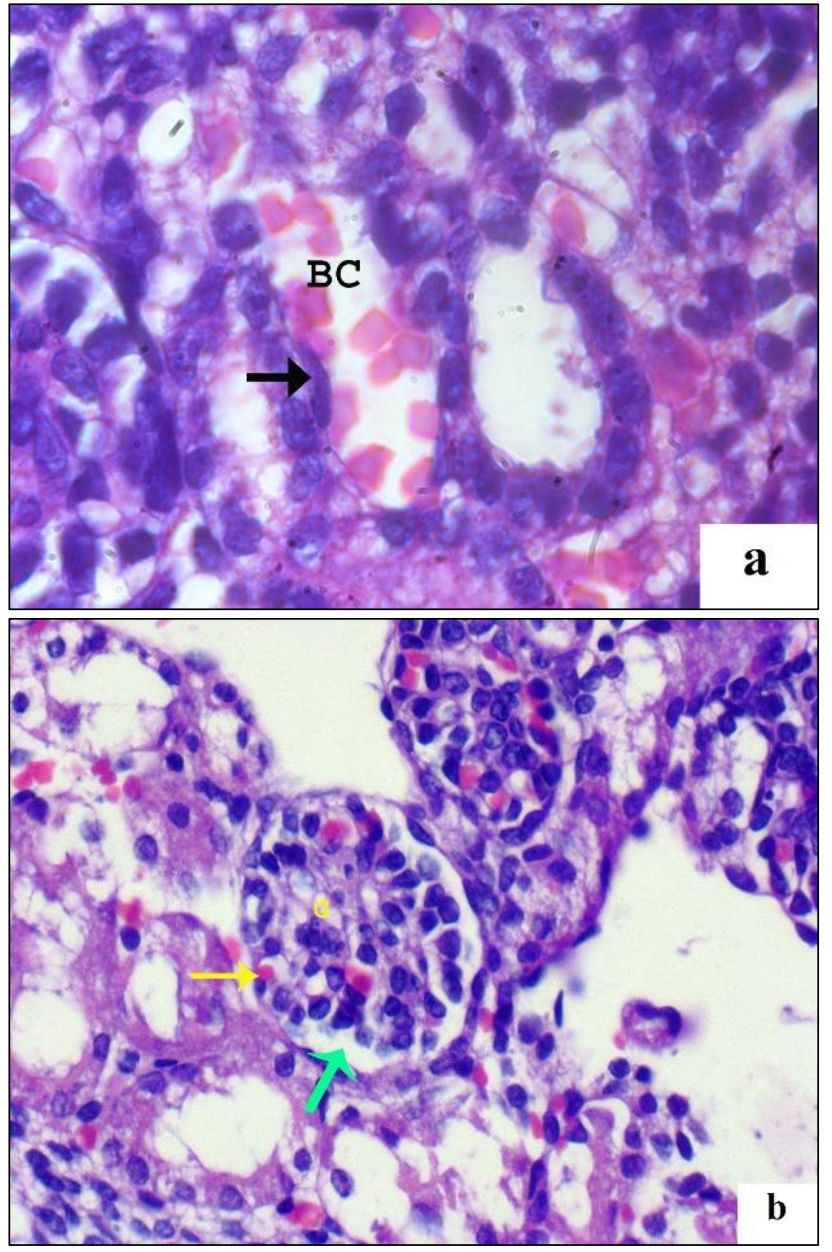

Figure 4: Photomicrographs of mice fetal kidney (Group D): (a) Interlobular artery lined with endothelium (arrow) containing blood cells (BC) in the lumen. H\&E, X400. (b) The renal corpuscle showing glomerular tuft $(G)$, capillary endothelium with normal blood cells (yellow arrow), Bowman's space (green arrow). H\&E, X200.

Table 3: Multiple Comparison of mean scoring for histological changes in blood vessels of fetal Kidneys per 10 fields among various groups according to Tukey test.

\begin{tabular}{cccc}
\hline \multicolumn{2}{c}{ Comparison among groups } & Mean Difference & Level of Significance \\
\hline Groups $(\alpha)$ & Group compared $(\beta)$ & $(\alpha-\beta)$ & p-value \\
\hline & (B) & -6.0 & $0.000^{*}$ \\
(A) & (C) & -1.1 & $0.000^{*}$ \\
& (D) & -3.8 & $0.000^{*}$ \\
(B) & (C) & 5.0 & $0.000^{*}$ \\
(C) & (D) & 2.3 & $0.000^{*}$ \\
& (D) & -2.7 & $0.000^{*}$ \\
\hline
\end{tabular}

* The mean difference is statistically highly significant among all groups. 
Table 4: Comparison of frequency of changes in renal blood vessels of mice fetal kidneys in 10 fields among various groups.

\begin{tabular}{lccccccccc}
\hline \multirow{2}{*}{ Histology } & \multicolumn{2}{c}{$\mathrm{A}$} & \multicolumn{2}{c}{$\mathrm{B}$} & \multicolumn{2}{c}{$\mathrm{C}$} & \multicolumn{2}{c}{$\mathrm{D}$} & \multirow{2}{*}{ Total } \\
\cline { 2 - 8 } & Freq & $\%$ & Freq & $\%$ & Freq & $\%$ & Freq & $\%$ & \\
\hline Mild change & 40 & 100.0 & - & - & 40 & 100.0 & 7 & 17.5 & $54.4 \%$ \\
Moderate change & - & - & 21 & 52.5 & - & - & 33 & 82.5 & $33.8 \%$ \\
Severe change & - & - & 19 & 47.5 & - & - & - & - & $11.9 \%$ \\
Total & 40 & 100.0 & 40 & 100.0 & 40 & 100.0 & 40 & 100 & $100.0 \%$ \\
\hline
\end{tabular}

\section{DISCUSSION}

In sodium arsenate exposed group (B) interlobular arteries demonstrated congestion, endothelial thickening and glomerular capillary tufts exhibited hemorrhages (Fig.2 a\& b). This is indicative of changes in the vascular endothelium due to the oxidative stress generated by sodium arsenate. Jomova et.al 2011, suggested that sodium arsenate disrupted the endothelial dependent vasorelaxation system by oxidative stress and induces atherosclerosis. ${ }^{11}$ In another study researchers revealed the formation of atheromatous plaques in walls of aorta after 8 weeks of exposure of mice with arsenic. ${ }^{12}$ Arsenic alters the lipid metabolism and induces atherosclerosis leading to hypertension and cardiovascular diseases. ${ }^{13}$ Arsenic induced reactive oxygen species (ROS) alters the vascular endothelium and the release of vasoactive mediators leading to upsurge in blood pressure. ${ }^{14}$

In groups $\mathrm{C} \& \mathrm{D}$ the vascular congestion and endothelial thickening had been reduced due to the antioxidant properties of vitamins $\mathrm{C} \& \mathrm{E}$ which stabilizes the cell membranes and thus reduces the congestion (Figs $3 \& 4$ ). Krohn et.al 2016, used selenium fortified lentil diet to reduce arsenic induced atherosclerosis. ${ }^{15}$ Researchers in a study used sea buckthorn which is a rich source of vitamins to prevent cardiovascular diseases. ${ }^{16}$ Shankar et.al 2016, used curcumin a rich source of antioxidants against sodium arsenite-induced renal and neuronal oxidative damage in rats. ${ }^{17}$ In addition to cardiovascular diseases the cerebrovascular dysfunctions like stroke have also been linked with consumption of arsenic contaminated drinking water. ${ }^{18}$ Arsenic mediated toxicity is due to mitochondrial dysfunction, therefore the resarchers suggested the investigation of mito-protective antioxidants. ${ }^{19}$ Various scientists have investigated the pathophysiological mechanisms of arsenic mediated cardiovascular disorders and have proposed measures to prevent the injuries inflicted by arsenic. ${ }^{20}$ The antioxidant role of Vitamins $\mathrm{C}$ and $\mathrm{E}$ had also been studied by various workers, this study evaluated the potential of these vitamins to avert the oxidative stress which steered towards vascular dysfunction triggered by arsenic.

\section{CONCLUSIONS}

This study concludes that the sodium arsenate initiated the renal vascular endothelial thickening and leakage by oxidative stress which predisposes the vasculature to atherosclerosis leading to hypertension and cardiovascular diseases. Vitamins C \& E forfended the damaging effects of arsenic. Vascular disorders can be prevented at an early stage of development by providing the safe drinking water and vitamin supplementation.

\section{DISCLOSURE OF INTEREST}

The authors report no conflict of interest.

\section{ACKNOWLEDGEMENTS}

The author acknowledges the support provided by the laboratory staff of department of anatomy of University of Health Sciences, Lahore.

\section{ETHICAL APPROVAL}

The study was approved by the Ethical Review Committee of University of Health Sciences, Lahore, Vide reference No. UHS/Education/126-06/1063 dated August 22, 2006.

\section{REFERENCES}

1. Ellinsworth DC. Arsenic, reactive oxygen, and endothelial dysfunction. J Pharmacol Exp Ther .2015 Jun; 353(3):458-464.

2. Singh AP, Goel RK, Kaur T. Mechanisms pertaining to arsenic toxicity. Toxicol. Int. $2011 \mathrm{Jul}$; 18(2):87.

3. Chakraborti D. Is WHO guideline value of arsenic in drinking water $10 \mathrm{ppb}$ in the developing countries safe to drink? Blde Univ J Health Sciences. 2016 Jan; 1(1):57.

4. Robles-Osorio ML, Sabath-Silva E, Sabath E. Arsenicmediated nephrotoxicity. Ren Fail. 2015 Apr; 37(4):542-547.

5. Sharma B, Sharma PM. Arsenic toxicity induced endothelial dysfunction and dementia: pharmacological interdiction by histone deacetylase and inducible nitric oxide synthase inhibitors. Toxicol. Appl. Pharmacol.”. 2013 Nov; 273(1):180-188. 
6. Waghe P, Sarath TS, Gupta P, Kandasamy K, Choudhury S, Kutty HS, et al. Arsenic causes aortic dysfunction and systemic hypertension in rats: Augmentation of angiotensin II signaling. Chem. Biol. Interact. 2015 Jul; 237: 104-114.

7. Wang Y, Zhao H, Nie X, Guo M, Jiang G, Xing M. Zinc application alleviates the adverse renal effects of arsenic stress in a protein quality control way in common carp. Environ. Res. 2020 Dec; 191:110063.

8. Kesavan M, Sarath TS, Kannan K, Suresh S, Gupta P, Vijayakaran K, et al. Atorvastatin restores arsenicinduced vascular dysfunction in rats: modulation of nitric oxide signaling and inflammatory mediators. Toxicol. Appl. Pharmacol. 2014 Oct; 280(1):107-116.

9. Kaur J, Reddy K, Balakumar P. The novel role of fenofibrate in preventing nicotine-and sodium arseniteinduced vascular endothelial dysfunction in the rat. Cardiovasc. Toxicol. 2010 Sep; 10(3):227-238.

10. Flora SJ. Arsenic-induced oxidative stress and its reversibility. Free Radic Biol Med. 2011 Jul; 51(2):257-281.

11. Jomova K, Jenisova Z, Feszterova M, Baros S, Liska J, Hudecova D, et al. Arsenic: toxicity, oxidative stress and human disease. J Appl Toxicol. 2011 Mar; 31(2):95-107.

12. Lemaire M, Lemarié CA, Flores Molina M, Schiffrin EL, Lehoux S, Mann KK. Exposure to moderate arsenic concentrations increases atherosclerosis in ApoE mouse model. Toxicol Sci. 2011 Jul; 122(1):211-221.

13. Cheng TJ, Chuu JJ, Chang CY, Tsai WC, Chen KJ, Guo HR. Atherosclerosis induced by arsenic in drinking water in rats through altering lipid metabolism. Toxicol Appl Pharmacol. 2011 Oct; 256(2):146-153.

14. Singh AP, Goel RK, Kaur T. Mechanisms pertaining to arsenic toxicity. Toxicol. Int. 2011 Jul; 18(2):87.
15. Krohn RM, Lemaire M, Silva LF, Lemarié C, Bolt A, Mann KK, et al. High-selenium lentil diet protects against arsenic-induced atherosclerosis in a mouse model. J Nutr Biochem. 2016 Jan; 27:9-15.

16. Xu YJ, Kaur M, Dhillon RS, Tappia PS, Dhalla NS. Health benefits of sea buckthorn for the prevention of cardiovascular diseases. J. Funct. Foods 2011 Jan; 3(1):2-12.

17. Sankar P, Telang AG, Kalaivanan R, Karunakaran V, SureshS, Kesavan M. Oral nanoparticulate curcumin combating arsenic-induced oxidative damage in kidney and brain of rats. Toxicol Ind Health. 2016 Mar; 32(3):410-421.

18. Lisabeth LD, Ahn HJ, Chen JJ, Sealy-Jefferson S, Burke JF, Meliker JR. Arsenic in drinking water and stroke hospitalizations in Michigan. J Stroke. 2010 Nov; 41(11):2499-2504.

19. Pace C, Dagda R, Angermann J. Antioxidants protect against arsenic induced mitochondrial cardio-toxicity. Toxics. 2017 Dec; 5(4):38.

20. Stea F, Bianchi F, Cori L, Sicari R. Cardiovascular effects of arsenic: clinical and epidemiological findings. Environ. Sci. Pollut. Res .2014 Jan; 21(1):244-251.

\section{AUTHORS' CONTRIBUTION: \\ FQ: Conception, design, manuscript writing, Data collection, Data analysis \\ MT: Critical review, Supervision of research}

